\title{
ASXL1 wt Allele
}

National Cancer Institute

\section{Source}

National Cancer Institute. ASXL1 wt Allele. NCI Thesaurus. Code C97321.

Human ASXL1 wild-type allele is located in the vicinity of $20 \mathrm{q} 11$ and is approximately $81 \mathrm{~kb}$ in length. This allele, which encodes putative Polycomb group protein ASXL1, may play a role in the regulation of both chromatin structure and transcription. Mutation of the gene is associated with both myelodysplastic syndromes and chronic myelomonocytic leukemia. 